
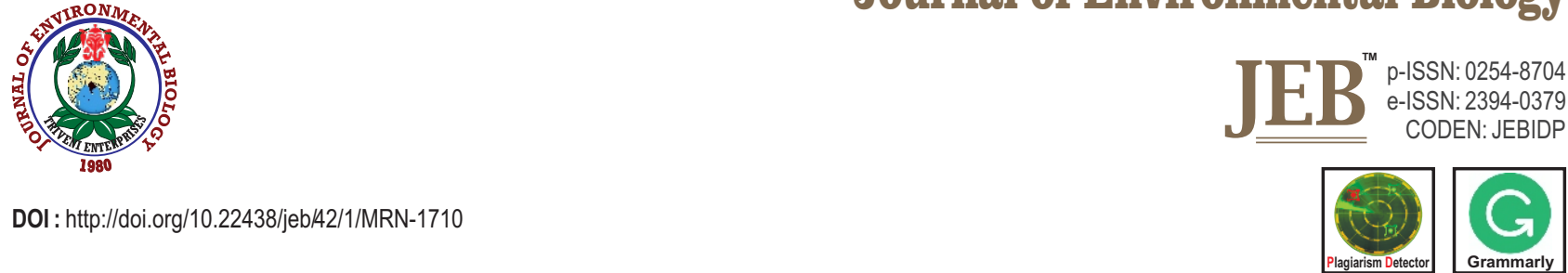

\title{
Applications and limitations of DNA barcoding in Environmental Biology
}

\author{
E.M. Hallerman \\ Department of Fish and Wild life Conservation, Virginia Polytechnic Institute and State University, Blacksburg, VA24061, United States \\ *Corresponding Author Email : ehallerm@vt.edu
}

\section{Abstract}

Species identification is often difficult, especially for early life-history stages, poorly known species within diverse taxa, and microbes. Molecular genetics has contributed the technique of DNA barcoding, offering a low-tech, potentially high-impact tool for identification of species. After briefly describing a range of applications, this review focus on its use for identification of larval fishes.

Molecular identification of larval fishes would increase knowledge of larval fish ecology, providing insights into reproductive ecology and population dynamics, and contribute to identification and protection of critical habitat. Other applications of environmental interest include identification of species from fecal starting material and forensic investigation. Limiting application of DNA barcoding is the environmental community's unfamiliarity withthe technique and limited development of DNA sequence archives for some taxa.

Key words: COI, Larval fishes, Molecular scatology, Species identification

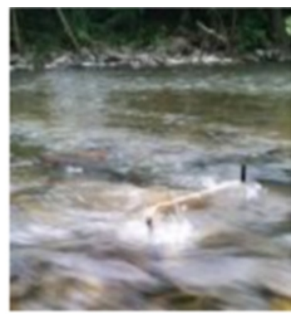

Field collection

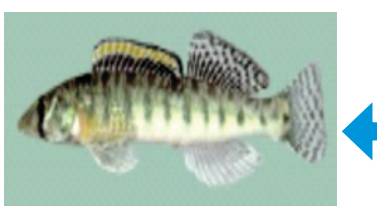

Species $\mathrm{ID}=$ Percina $r e x$

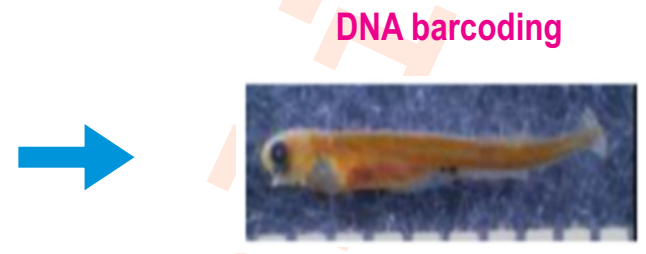

Larval fish

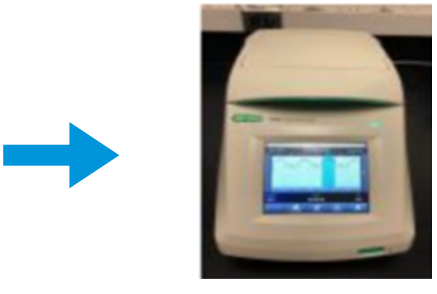

PCR amplification

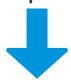

Cytochrome Oxidase Subunit 15 ' region $\quad .652$ bp

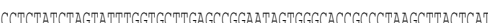
CCGAGCAGAGCTGAGCCAACCCGGCGCACTCCTCGGGGACGATCAGATTTATAACGTCAT

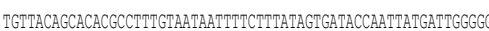
CTTTGGAARCTGACTCGTGCCCCTAATGATCGGCGCCCCCGACATGGCGTTTCCCCGAA ARACAACATGAGCTTCTGACTPTTGCCCCCCTCCTTCCTCCTACTTCTTGCCTCCTCCGG AgTAGAAGCAGGGGCTGGAACCGGGTGGACCGTCTACCCGCCTCTGGCGGGTAACTTAGC ACACGCCGGGGCATCCGICGATTTAACCATCTICTCCTIGCATCTGGCAGGTATTTCTTC AатTCTAGGGGC TATTAATTTTATTACGACGATTATTAACATARAаCCCCCCGCCATCTC AATTCTAGGGGC PATPAATTTTATTACGACGATTATTAACATAAAACCCCCCGCCATCTC TCAATACCAGACACCCCTATTTGTGIGAGCCGITCTAATCACIGCIGIACTACITCITC СACTTTCTITGACCCGGCGGGAGGGGCGACCCCATTCTTPATCAACACTTA

COI DNA sequence

BLAST search results

How to cite : Hallerman, E.M.: Applications and limitations of DNA barcoding in Environmental Biology. J. Environ. Biol., 42, 1-13 (2021). 


\section{Introduction}

Correct species identification is fundamental for studies of environmental biology. Yet, species identification is often difficult, especially for early stages of life cycle of animals that metamorphose, poorly known species within diverse taxa, and microbes. Often it is difficult to identify a specimen on morphological basis because it is very small (instar-stage arthropods, larval fishes) or in compromised condition (animal parts, partially digested items in a predator's stomach). In other applications, a researcher may want to determine the species presented at a site indirectly, perhaps by identifying the source of collected fecal material. Molecular genetics has contributed the technique of DNA barcoding, offering a low-tech, often highimpact tool for identification of species. DNA barcoding utilizes species-specific DNA sequences archived in a taxonomic database (Herbert et al., 2003a; Kress and Erikson 2008) as a reference for subsequent identification and analysis (Ratnasingham and Hebert 2007; Ivanova et al., 2007).

Genetic identification of metazoan animals is most often accomplished through amplification and sequencing of mitochondrial cytochrome oxidase I - subunit 3 (COI) gene (Ivanova et al., 2007; Weigt et al., 2012), although cytochrome b (cytb) is also used widely (Branicki et al., 2005). Barcoding in plant systems may use any of several systems (Hollingsworth et al., 2011), including ribulose bisphosphate carboxylase long chain ( $r c b L)$, nuclear ribosomal internal transcribed spacer (ITS) region, and plastid trnH-psbA intergenic spacer region (Kress et al., 2005). Fungi are most often identified using nuclear ITS region (Seifert 2009, Begerow et al., 2010, Schoch et al., 2012, Hyde et al., 2013). Microbial identification is often pursued using 16S ribosomal RNA gene (Woese and Fox 1977). The targeted DNA sequence is amplified with either universal or taxon-specific primers using polymerase chain reaction (PCR) (Ivanova et al., 2007). DNA sequencing results are then compared with archived entries in the Barcode of Life (http:// www. boldsystems. org/), GenBank (https:// www. ncbi. nlm. nih. gov/nucleotide/), or other data bases using the Basic Local Alignment and Search Tool (Altshul et al., 1990) or one of its subsequent derivatives.

DNA barcoding has proved to be useful in a diverse range of applications. For example, fisheries applications (Bhattacharya et al., 2016) include identifying members of complex fish assemblages on Australia's coral reefs (Ward et al., 2005), and characterizing the diets of lionfish Pterois sp. (Cote et al., 2013), giant squid Archituthus dux (Deagle et al., 2005), largemouth bass Micropterus salmoides (Jo et al., 2013), and other predators (Smith et al., 2005; Martinez et al., 2011). In the context of an ecological invasion impact assessment study, Moran et al. (2016) demonstrated DNA barcoding to be effective and cost-efficient for identifying otherwise unidentifiable prey items in the stomach contents of non-native ictalurid catfishes in Virginia, USA. Hilling et al. (2018) applied the approach to identify non-indigenous notchlip redhorse Moxostoma collapsum that were found in the New River of Virginia.
While in most contexts, barcoding has been applied to DNA isolated directly from a specimen of interest, in others, it can also be applied to DNA from an unknown source collected from the environment. Environmental DNA, termed eDNA, is the genetic material present in environmental samples such as sediment, water and air, which may include whole cells, extracellular DNA and potentially whole organisms (Ficetola et al., 2008, Barnes and Turner 2016). eDNA may come from skin, mucous, saliva, sperm, other secretions, eggs, feces, urine, blood, roots, leaves, fruit, pollen, and decomposing bodies of larger organisms (Bohmann et al., 2014, Barnes and Turner 2016). DNA is isolated from the sample, and targeted DNA sequences, often those used for DNA barcoding, are amplified using PCR or quantitative PCR. The amplification product is then sequenced and the resulting DNA sequence is compared with those in a DNA sequence archive. eDNA assays are commonly used, especially to detect cryptic or rare aquatic species. For example, eDNA was used to track the spread of invasive American bullfrog Lithobates catesbeianus in Europe (Ficetola et al., 2008) and to detect silver carp Hypophthalmichthys molitrix in Lake Michigan in the United States (Jerde et al., 2011). eDNA proved useful for detecting the Idaho giant salamander, Dicamptodon aterrimus (Goldberg et al., 2011), which is difficult to observe or collect because it nests in rocky hollows in fast-flowing rivers of the American West. There is growing interest in using eDNA as a tool to monitor biodiversity (Thomsen et al., 2012), and some notable successes have been achieved in monitoring imperiled species (slackwater darter Etheostoma boschungi Janosik and Johnston 2015). However, development of any eDNA assay represents a tradeoff between sensitivity (the ability to detect a target species' DNA) and specificity (the ability to distinguish that species' DNA from that of other species in that ecosystem). Many if not most successful eDNA assays have targeted unique native (Idaho giant salamander - Goldberg et al., 2011) or introduced (American bullfrog - Ficetola et al., 2008, silver carp - Jerde et al., 2011) species lacking congeners in focal ecosystems, where high sensitivity can be focused upon. Among the technical issues, degradation of eDNA in the environment limits the scope of eDNA studies, as often only small segments of genetic material remain, particularly in warm, tropical regions (Ruppert et al., 2019). The highly variable concentrations of eDNA and potential heterogeneity through the water body makes it essential that the procedure is optimized, ideally with a pilot study for each new application to ensure that the sampling design is appropriate to detect the target species (Goldberg et al., 2016, Deiner et al., 2017). Bohman et al. (2014) documented a thorough review of eDNA applications.

DNA barcoding is based upon amplification and sequencing of a target gene in DNA isolated from an individual specimen. The approach should not be confused with DNA metabarcoding, in which all DNA sequences in a sample containing DNA of multiple individuals or species are amplified, sequenced, and the respective source species identified. Metabarcoding may be defined as the use of general or "universal" PCR primers on mixed DNA samples from any origin 
followed by high-throughput next-generation sequencing to determine the species composition of the sample. While this approach has been widely used in microbiology, only more recently has it found widespread utility in identification of macroorganisms (Coissac et al., 2012, Creer et al., 2016, Deiner et al., 2017). Because of the potential complexity of the species mix in a sample, the methods for DNA metabarcoding are more complex than for classical barcoding. Primers for eDNA metabarcoding need to be short enough to amplify degraded samples, identical within but variable between species, and annealing to highly conserved DNA sequences in order to amplify a variety of species without sacrificing the specificity for a target group (Epp et al., 2012). Next-generation sequencing often results in millions of DNA sequence reads. As there may be several species within the sample analyzed, analysis of the results involves use of complex bioinformatics "pipelines". The respective DNA sequences typically are grouped into operational taxonomic units which differentiate species or other taxa based on the similarity of their DNA sequences, which may be related to those of known species by comparing to archived sequences of known species identity. Ruppert et al. (2019) reviewed the methodological and bioinformatics considerations for eDNA metabarcoding studies, summarizing applications, and reviewing the results of published eDNA metabarcoding studies to date.

General effectiveness of DNA barcoding methodology in taxonomy: $\mathrm{CO}$ is selected as a DNA barcoding gene for animals because its DNA sequence tends to vary relatively little within species and relatively much between species (across the animal kingdom - Hebert et al., 2003b, among birds - Tavares and Baker 2008). Because of this property, $\mathrm{CO}$ l sequences can provide a preliminary test of species boundaries using phylogenetic analyses, with polyphyly of results (i.e., lineages being been grouped together that do not share an immediate common ancestor) suggesting the need for further phylogenetic testing using a full battery of molecular and morphological characters. Screening of $\mathrm{CO}$ sequences has thus led to recognition of cryptic species, as in plants like Dumasia, a genus of legumes (Jiang et al., 2020) and insects like aphids (Wang and Qiao 2009) and fruit flies (Fu et al., 2016).

Freshwater fishes provide a useful illustration of such applications. The freshwater fish fauna is most diverse in the Neotropical region, with approximately 6,000 recognized species. These species are distributed among 17 orders, with almost $80 \%$ belonging to Orders Characiformes (characids), Siluriformes (catfishes) and Perciformes (perches). Molecular differentiation shows that most diversification of this fauna occurred recently, complicating taxonomy and field identification. Against this background, Pereira et al. (2013) tested the effectiveness of DNA barcoding methodology in 254 species of fishes from the Upper Paraná River basin of Brazil, an area taken as representative of the larger Neotropical region. Of the 254 species analyzed, 252 were correctly identified using barcode sequences, indicating the utility of approach.
Among Neotropical freshwater fishes, characiforms are the most diverse group. The most diverse family of this order is Characidae, with more than 1,350 recognized species (Froese and Pauly 2020). Given its species diversity, Family Characidae is not surprisingly the Neotropical fish family with the most taxonomic problems (Oliveira et al., 2011). One such set of problems is presented by Piabina argentea, a nominal species that may be comprised of more than one biological unit in the upper Paraná basin of Brazil. Pereira et al. (2011) analyzed partial mitochondrial $\mathrm{CO}$ and cytb gene sequences for 58 specimens drawn from 13 localities. Their phylogenetic analysis revealed six major clusters of sequences, supporting the interpretation that the widely distributed species $P$. argentea as currently defined actually represents more than one species, and possibly as many as six.

In another such case, Nannostomus is a genus of 20 characid species with elongated body shape, popularly known as pencilfishes. Even though the genus has undergone more than one taxonomic revision, it still possesses poorly defined species. Benzaquem et al. (2015), applied DNA barcoding for assessing 14 pencilfish species, and observed deep lineage divergences within $N$. digrammus, $N$. trifasciatus, $N$. unifasciatus, and $N$. eques. In particular for $N$. digrammus and $N$. trifasciatus, the estimated divergences in some lineages were so high that their conspecific status is questionable. Noting that the characid genus.

Astyanax has many systematic and taxonomic uncertainties, Rossini et al. (2016) analyzed COl sequences of Astyanax collections covering almost its entire area of occurrence. The results of application of different species delimitation approaches (ABGD, GMYC and BIN) supported their use of a criterion value of $2 \%$ divergence for distinguishing putative species. Their results indicated the existence of five distinct Astyanax lineages. Some groups, such as trans-Andean Mountain forms, mostly composed of well-defined species, but in others a number of nominal species were clustered together, suggesting the need for further study and likely taxonomic revision.

Brycon is a genus of Neotropical fishes within Order Characiformes, with 44 valid species in Central and South America. Many Brycon species are important fishery resources, and some are farmed. Morphological and molecular studies have suggested that the group is not monophyletic (having a single common ancestor), with a number of unresolved taxonomic problems. Arruda et al. (2019) sequenced the COI gene and applied phylogenetic analyses using the GMYC and ABGD species delimitation approaches. Their results indicated at least 31 distinct molecularly defined operational taxonomic units within 18 species identified a priori based on morphology. Many of these lineages will require further investigation to support more definitive classification.

Taken together, these case studies demonstrate the efficacy of DNA barcoding for discovering hidden diversity in 
Neotropical freshwater fishes, and suggest its utility for alpha taxonomy more generally. Beyond fishes, $\mathrm{COI}$ sequences have shown other vertebrate taxa to be polyphyletic, for example, the frog family Ranidae (Huang et al., 2016).

DNA barcoding and larval fish ecology: Current knowledge of stream fish ecology is largely based on observations of post-larval stages. Year-class strength and population dynamics, however, are often driven by larval recruitment to juvenile life stage (Johnston et al., 1995). Spatial and temporal patterns of larval dispersal and habitat use are unexplored for most species, especially for freshwater species (Niles et al., 2009; Falke et al., 2010; Naus et al., 2018) and species lacking economic importance. To relate abundance of larval fishes to population persistence and dynamics, better understanding of the ecology of fish larvae is needed. Unfortunately, studies of larval fish are relatively scarce due to difficulty in collecting them effectively and identifying individuals to species (Kelso et al., 2012). Identification of larval fishes to species is complicated by their rapid progress through different developmental stages and poorly defined expression of morphological or morphometric characters that do distinguish closely related species at later life stages. When closely related species occur in an ecosystem system, investigators often cannot reliably identify larval fishes to species (Niles et al., 2009; Naus et al., 2018). For some purposes, such as conservation, identification of species is critical.

DNA barcoding has been applied to characterize larval fish aggregations in various ecological contexts. Pegg et al. (2006) applied DNA barcoding to identify fish larvae in highly diverse southern Great Barrier Reef of Australia. Valdez-Moreno et al. (2010) examined early life-stages of marine fishes from the Yucatan Peninsula of Mexico and showed range extensions, previously overlooked taxa, and new information about spawning ecology of hogfish, Lachnolaimus maximus. Burghart et al. (2014) applied DNA barcoding and showed disparity between the compositions of planktonic fish egg and larval communities within Tampa Bay, Florida, USA. DNA barcoding has shown complex reproductive interactions among stream-dwelling cyprinid fishes associated with gravel nests built by chubs Nocomis sp. (Cashner and Bart 2010, Peoples et al., 2017; Silknetter et al., 2019). Comparison of DNA barcoding and morphological identification of larval fish and embryos from Lake Huron in Canada (Hulley et al., 2018) showed that while each method has its strengths and weaknesses, barcoding was more costeffective and efficient for monitoring at a large scale. Applications of DNA barcoding to study freshwater fish larval ecology, however, remain relatively few.

The potential benefits and technical issues pertaining to application of DNA barcoding to larval fishes has been demonstrated by Buckwalter et al. (2019). The upper Roanoke River in Virginia in the eastern United States is home to six species of darters, small members of Family Percidae, the perches. These darters include threatened Roanoke logperch Percina rex, which is endemic to the Roanoke, Dan, and
Nottoway river basins of Virginia and North Carolina. Little was known about the larval ecology of Roanoke Logperch or the other five darters ( $P$. nevisense, $P$. roanoka, Etheostoma podostemone, $E$. nigrum, and $E$. flabellare) in the upper Roanoke system, including their respective times of emergence from benthic nests and larval dispersal. Further, meagre information is available on distinguishing Roanoke logperch larvae from those of other darters. Such knowledge is crucial for assessing demographic vulnerability of and limitations to recovery of Roanoke logperch populations, especially with regard to managing anthropogenic impacts (e.g., water withdrawals, urbanization) that can affect juvenile recruitment. In particular, the river reaches that function as reliable sources of recruitment or the extent of dispersal by larval Roanoke Logperch were unknown.

Buckwater et al. (2019) collected 12,762 larval and juvenile fishes from the Roanoke River in 2015 and 10,258 in 2018. Using morphological and pigmentation characters, 3,433 were identified as larval darters, but lacking dichotomous keys for larval darters in that ecosystem, the authors attempted to apply DNA barcoding. They found that two sets of 'universal' fish polymerase chain reaction primers (Ivanova et al., 2007) failed to amplify DNA of darter larvae, even after considerable troubleshooting. Upon close examination of April et al. (2010), they noted that species of interest were not included in those results and inferred that the primers were not well suited for amplifying DNA of Percina, the genus including species of focal interest. The authors designed custom primers using DNA sequences retrieved from GenBank. They used the Primer Blast tool (Ye et al., 2012) to identify and then validate candidate primer pairs for the mitochondrial COI, ND2, and cytb regions. DNA barcoding is mostly based on the $\mathrm{CO}$ I gene and there is a large reference database, they went forward with amplifications of $\mathrm{COI}$ for unidentified percid larvae. Even so, there were yet two species in the Roanoke basin that were not distinguished on molecular basis-E. nigrum and $E$. podostemone. They are closely related phylogenetically; screening of a longer fragment of $\mathrm{CO}$ gene or of other mitochondrial sequences (Near et al., 2011) might provide the basis for development of diagnostic barcoding markers. Similar issues were found regarding the inability of $\mathrm{COI}$ to resolve members of Genus Coregonus, the whitefishes, by Hulley et al. (2018). Such experiences provide a cautionary note for those contemplating use of DNA barcoding experiments in systems with congeners. Amplified DNA sequences for 1,351 larvae matched archived mitochondrial cytochrome oxidase I sequences for darters occurring in the ecosystem. With molecular identifications in hand, larval darters were classified to genus with $100 \%$ accuracy using the ratio of pectoral fin length to body length; however, identification of species using morphometrics alone was subject to a misclassification rate of $11.8 \%$, which can be resolved by considering pigmentation patterns (Buckwalter et al., 2019). Application of molecular genetic and phenotypic tools to larval fish identification can advance understanding of larval darter ecology. For example, in the Roanoke River system, Buckwalter et al., (2019) noted that larval Percina species appeared in the drift before Etheostoma species in both study years. They identified 
key areas of the upper Roanoke watershed used by three Percina species, including Roanoke logperch. This knowledge could be applied to designate and protect critical habitat for this threatened species. With a larger dataset, linkages might be sought among water temperature, river discharge, day length, and darter spawning periods. Such tools would be suitable for evaluating environmental impacts of water withdrawal, for example, for assessing the impact of using river water to drive turbines in an electric power plant.

The results of this case study suggest that DNA barcoding and phenotypic methods can be extended to other species groups, river systems, and environmental studies. However, some caveats must be applied on application of DNA barcoding methods. As noted above, "universal" $\mathrm{COI}$ polymerase chain reaction primers do not prove useful for every species, and in cases where they do not, data may be lost or time must be invested in developing species-specific PCR primer sets for focal species. While they have improved markedly over the past decade, DNA sequence archives (notably Barcode of Life and GenBank) are not complete, an important issue discussed below. The species associated with DNA sequences in the respective archives are not always correct or reflect current taxonomy, creating uncertainty and possibility of error in identifications subsequently made using those archived sequences.

DNA barcoding is based on mitochondrial gene sequencing, and identifies only the female contribution to an individual. Hence, DNA barcode does not detect instances of interspecific hybridization, which is well known to occur in freshwater fishes (Campton 1987), birds (Kerr et al., 2007), and other taxa (Dinca et al., 2010). In cases where hybridization is possible, detection of hybrids would require addition of nuclear DNA sequences or phenotypic characters (Scribner et al., 2000).

A poignant example of the issue of incorrect species identification in reference archives is provided by Peoples et al. (2017), who examined the complex interactions of multiple cyprinid species that spawn in gravel nests constructed and guarded by male chubs Nocomis $s p$. in streams and rivers of the southeastern United States. Among species identified by barcoding DNA extracted from eggs collected from a bluehead chub N. leptocephalus mound in the James River watershed of Virginia, USA were 44 putative identifications of bigmouth chub $N$. platyrhynchus, which does not occur in that watershed. Recent evidence reveal widespread cryptic diversity, between five and 11 unrecognized species, within what is recognized as "bluehead chub" (Nagle and Simons 2012). Because bluehead chub is a polyphyletic group that includes a clade of bigmouth chub, the identification of Catawba Creek larvae as the latter suggests that those individuals likely belonged to a bluehead chub clade that was more closely related to bigmouth chub than to the bluehead chub included in the April et al. (2011) study, which is the sole source of Nocomis sequences archived in GenBank. Another possibility is that the museum specimens of bigmouth chub described by April et al. (2011) were in fact bluehead chub that had been misidentified.

Whatever the true explanation, knowledge of potential pitfalls facing molecular identification of larval fishes should inform future studies. Molecular ecologists should apply DNA barcoding for species identification critically. Because DNA barcoding of individual larvae can be time-consuming, and hence, costly, Nobile et al. (2019) developed a protocol based on DNA metabarcoding to investigate whether it is possible to detect and quantify all species present in a pool of ichthyoplankton. Their results using next-generation sequencing showed high accuracy in species detection, ranging from $83 \%$ to $100 \%$, with an average of $95 \%$ among all samples. Application of this approach may accelerate advances in understanding larval fish ecology.

Molecular scatology, or species from feces: It is often difficult or dangerous to capture animals in the wild because they are rare, elusive or dangerous. Yet, such species may leave traces, including fecal material on the landscape, which can be collected and analyzed using DNA barcoding methodology to identify the species. This approach has variously been termed "molecular scatology" or "species from feces". The species that produced fecal sample can most readily be determined by sampling its outer surface, isolating and barcoding DNA that was sloughed from host intestinal cells.

Chaves et al. (2012) assessed the utility of alternative DNA barcoding markers, and showed mitochondrial ATP6 and $\mathrm{CO}$ l sequences to be useful for species-level identification of mammalian carnivores from scat. Rodger and Janečka (2013) reviewed studies using fecal barcoding to study wild felids, provided an overview of field, laboratory and analytic techniques, and suggested how such studies can support conservation. Using classical morphology and DNA barcoding to identify scats of five sympatric carnivores in the Himalaya Mountains of Pakistan, Akrim et al. (2018) showed that morphological identification of scats is subject to error and can result in wrong wildlife management decisions. Because DNA from scat samples in warm, humid ecosystems is likely to be degraded, use of more than one molecular marker would lead to more reliable species identification. Testing a set of new barcoding primers for the mitochondrial $12 S$ subunit 1 rRNA, 12S subunit 2 rRNA, and $16 S$ rRNA regions for Neotropical felid and canid species, RodriguezCastro et al. (2020) demonstrated an efficient primer set for reliable identification of South American carnivores. Seah et al. (2020) recently demonstrated that it is possible to generate accurate DNA barcode sequences from preserved and noninvasively collected scat, hair, and feather samples using portable MinION DNA sequencing platform, suggesting the possibility of rapid identification of source materials in the field. By carefully sampling the inner part of fecal bolus, investigators may gain an indication of prey species consumed using DNA barcoding for separable prey items or DNA metabarcoding for mixture of items (Jedlicka et al., 2017). 
Detailed consideration of a case study will indicate the potential of DNA barcoding of fecal materials. Order Chiroptera the bats - comprises the second-largest order of mammals, with over 1,400 species. Different bat species have different diets, including insects, nectar, pollen, fruit and even vertebrates. They are important in their respective ecosystems for preying upon insects, pollinating flowers and dispersing seeds; many tropical plants depend entirely on bats for these services. Due to their physiology, however, bats act as a reservoir for many pathogens, including rabies and Covid 19. Most bats are nocturnal, and many roost in caves, buildings, bridges or other refuges. These behaviors render bats difficult to identify in the field. Many bat species are of conservation concern. In North America, for example, the accidental 2006 introduction of Pseudogymnoascus destructans, the causal agent for white nose syndrome, has caused 13 species to decline precipitously (U.S. Fish and Wildlife Service 2020). DNA barcoding may be applied to resolve both basic and applied issues of bat biology.

The diversity of bat fauna is not well characterized in regions where it is especially diverse, such as Latin America, and DNA barcoding can contribute to recognition of cryptic species. Clare et al. (2007) assessed mitochondrial COI DNA barcoding for discrimination of 87 species of bats from Guyana; 81 of these species showed both low intraspecific variation (mean $=0.60 \%$ ), and clear the sequence divergence from their congeners (mean = $7.80 \%$ ), while other six showed divergent intraspecific lineages, suggesting species complexes. Clare et al. (2011) used DNA barcodes to survey known and potential species diversity in a collection of more than 9,000 individuals from 163 species of Neotropical bats; among 163 species found, 98.8\% possessed distinct sets of $\mathrm{CO} /$ haplotypes, making them easily recognizable. Examining variation of $\mathrm{CO}$ among 20 species of bats in Family Phyllostomidae in southeastern Mexico and Guatemala, Hernández-Dávila et al. (2012) found low intraspecific variation, although some taxa had intraspecific variation ranging up to $8.8 \%$, suggesting the possibility of cryptic species. Walker et al. (2016) developed an DNA barcode assay based on CO/ variation that proved highly discriminatory among members of Order Chiroptera-92\% species-level identification of barcoded speciesand validated the system with 54 bat species across suborders. Using $\mathrm{COI}$ sequences mined from Genbank and new sequences from collected samples, Korstian et al. (2016) tested the use of COI locus for DNA barcoding of all 47 bat species found in the United States; $80 \%$ of species examined had distinct barcodes, including most species currently listed as threatened or endangered. Using a different molecular marker, Brown et al. (2017) screened sequences from the mitochondrial $16 \mathrm{~S}$ ribosomal subunit to create a DNA sequence database for 16 species of bats known to occur in Tennessee, USA and demonstrated its usefulness in identifying southeastern bat species using guano.

Many bats are protected as imperiled species, and application of DNA barcodes can contribute to their conservation. Over half of bat species use human structures, such as buildings and bridges as day or night roosts (Kiser et al., 1999, Johnson et al., 2002, Geluso et al., 2018). Maintenance activities may be affected. For example, the Virginia Department of Transportation inspects bridges and other structures for signs of bat use before maintenance or construction activities go forward. Unless bats are visible and identified during field surveys, observation of bat guano indicates only that bat use has occurred; in the absence of definitive species identification, the agency must presume that use by a protected species cannot be discounted. Use of acoustic monitoring of bat calls can prove useful, but echolocation call quality around structures is often degraded (Coleman et al., 2014), and acoustics alone cannot be used to definitively prove or disprove bridge use by listed bats. Ongoing work is developing a reliable guano sampling and testing protocol to identify the species of bats occupying bridge structures, comparing the accuracy of the DNA-based identification protocol from guano versus that from acoustic surveys and mist netting as comparators. In other applied work, Korstian et al. (2016) used DNA barcoding to improve bat carcass identification at wind farms in the United States.

Other applications in environmental biology: Other environmental issues of interest might be approached using DNA barcoding methods. In terms of morbidity and mortality inflicted on human population, parasites and their vectors are among the most dangerous groups of animals on earth. While these groups have received considerable attention, taxonomic knowledge remains limited. Besansky et al. (2003) described how DNA barcodes offer opportunities studying parasite taxa that are largely under-represented in understanding of animal species. Parasite identification poses considerable challenges. In addition of being small, parasites develop through complex, multi-host life cycles, sometimes living within host tissues. They may reside in and on hosts as assemblages of many parasite species and cryptic species complexes. Only through proper parasite identification can researchers recognize reservoir hosts, as well as distinguish morphologically similar species that cause distinct pathologies (Hopkins etal., 1997; Sterud etal., 2002).

Besansky et al. (2003) suggested targeted application of DNA barcoding to mosquito vectors and their parasites, which include arboviruses, malaria parasites, and nematodes, for which morphometrics-based identifications are difficult or impossible. Subsequently, DNA barcoding methods have been broadly applied in studies of vectors and parasites, for example, mosquito vectors (Cywinska et al., 2006, Kumar et al., 2007), and flatworm (Olson and Tkach 2005), nematode (Ferri et al., 2009), and coccidian (Ogedengbe et al., 2011) parasites. While eDNA approaches provide a toolbox for environmental parasitology studies (Bass et al., 2015), there remain methodological and policy challenges.

A key sector of environmental biology concerns protection of species of conservation concern. Unfortunately, people often misappropriate individuals of protected species for personal use or commercial sale. Forensic tools often must be applied to investigate takings and identify suspects. In a typical 
case, a suspect is caught with material of an unknown species. Morphology-based identification can be difficult because animal parts are sold in trade and because of high morphological similarity among congeneric species. DNA barcoding can assist in the species-level identification of animal parts (Branicki et al., 2003, Dawnay et al., 2007).

A high-profile forensic case study brought the utility of molecular assays to broad attention. Baker et al. $(1994,1996)$ purchased a variety of whale products through commercial channels in Japan and Korea and sequenced 155-378 bp of mitochondrial DNA control region. Amplified DNA sequences for 16 products of unknown species affinity were aligned and compared to reference sequences for 16 cetacean species, in some cases including geographic variants. Eight samples grouped with either southern or northern minke whale Balaenoptera acutorostrata, one with humpback whale Megaptera novaeangliae, four with fin whale Balaenoptera physalus, two with dolphin species, and two were not clearly identified. Availability of some of the products could not be reconciled with legal catch records. A few minke whales are taken legally, but take of humpback and fin whales has been prohibited since 1966 and 1986, respectively. The simplest explanation was that products available in these seafood markets included species that had been hunted, processed, or marketed illegally.

Among examples of classical COI-based DNA barcoding, Bunholi et al. (2018) assessed potential crimes regarding landing and trade of endangered shark species along the coast of São Paulo state in Brazil. DNA barcoding revealed ongoing fishing and trafficking of spiny angelshark Squatina guggenheim $(n=75$ observations), hidden angelshark S. occulta $(n=5)$, and Brazilian guitarfish Pseudobatoshorkelii $(n=5)$, indicating that the current conservation and monitoring systems are not working effectively.

Molecular genetic tools can also be applied during fish processing and marketing. Munoz Colmenero et al. (2016) screened mitochondrial $\mathrm{CO}$ and cytb DNA sequences among 245 samples of fish sold in Spain. DNA sequences revealed $>7 \%$ frequency of mislabeling, unequally distributed among products, fish groups, and outlets where the respective samples were obtained. Many such instances of mislabeling, as higher-priced products, likely were deliberate. A significantly higher frequency of mislabeling was found for unrecognizable processed products than for whole fish. A lower frequency of mislabeling occurred in samples purchased from local grocery stores, with more in bigger supermarkets, wholesalers and restaurants. Such mislabeling is of interest because of the environmental consequences, as some species exploited are of conservation concern. Tope shark, Galeorhinus galeus is listed by the International Union for the Conservation of Nature as Near-Threatened, and its mislabeling was likely deliberate. Albacore tuna Thunnus alalonga is listed as Vulnerable, and its mislabeling may have been inadvertent. Ogden (2008) reviewed the use of DNA tools for improving compliance, traceability and enforcement in fishing industry.
Illicit labeling and sale is not limited to fish products. For example, much of the demand for turtle meat in North America and Europe during the past four centuries was met using green turtle Chelonia mydas and other marine turtles. As those stocks declined, harvest of alligator snapping turtle, Macroclemys temminckii, the largest freshwater turtle in NorthAmerica, increased and the species declined to the point that it is protected in every U.S. state, except Louisiana. There is concern that the remaining legal trade in turtle products may serve as a cover for illegally harvested species. To identify the species in commerce, Roman and Bowen (2000) purchased 36 putative turtle meat products in Louisiana and Florida. Using mitochondrial cytb and control region sequences, they identified 19 samples as common snapping turtle Chelydra serpentina, three as Florida softshell turtle Apalone ferox, one provisionally as softshell turtle Apalone sp., one as alligator snapping turtle, and eight as American alligator Alligator mississippiensis. Hence, M. temminckii no longer seems the predominant species in Louisiana markets. The presence of alligator meat in a quarter of the samples indicate that trade of turtle products is not completely legalized. As is often the case, large, esteemed species, such as green turtle and alligator snapper, have been replaced by smaller, more-abundant or mislabeled species.

The forensic cases cited in this passage regard specieslevel identification. For forensic applications involving populationor individual-level identification, other molecular markers would be used (Hallerman 2003). Applications of genetic markers to investigate wild life crime can be complex, particularly where crimes involve a wide range of species and evidential questions. Ogden (2010) examined issues relevant to setting up a DNA forensics laboratory, including models for operating individual laboratories and options for organizing forensic testing at the national and international levels. Book-length treatments of wildlife forensics (Huffman and Wallace 2012) provide a comprehensive treatment of all aspects of this topic.

Issue of unbarcoded species in reference archives: As noted above, arguably the greatest impediment to widespread application of DNA barcoding to problems in environmental biology is the incompleteness of reference databases. The degree of impediment varies among faunal groups, both regionally and globally.

Among 217 freshwater fish species occurring in Virginia (Jenkins and Burkhead 1994), 200 had archived DNA barcode sequences (Table 1). Of species lacking reference sequences, three were newly described or undescribed cyprinids, and four (one catostomid, ictalurid, fundulid, and percid) were narrow endemics, i.e., species with geographically small distributions. Five of the eight cottids (sculpins) had no reference sequences; their systematics and taxonomy are not well resolved, however, and Jenkins and Burkhead (1994) listed three undescribed endemics. The catostomid genus Scartomyzon (the jumprocks, with three species) had no reference sequences. The amblyopsid species, swampfish 
Table 1: Gaps in availability of DNA barcode reference sequences for freshwater fishes, by region and family, and for fishes generally. "?" denotes unclear relation between a barcode and an undescribed species

\begin{tabular}{lll}
\hline Family & $\begin{array}{l}\text { Number } \\
\text { of species }\end{array}$ & $\begin{array}{l}\text { Number } \\
\text { with } \\
\text { reference } \\
\text { sequences }\end{array}$ \\
\hline
\end{tabular}

\section{State of Virginia, USA ${ }^{1}$}

Petromyzontidae - lampreys

Acipenseridae - sturgeons

Polyodontidae - paddlefish

Lepisosteidae - gars

Amiidae - bowfin

Anguillidae - eels

Clupeidae - herrings

Esocidae - pikes

Umbridae - mudminnows

Cyprinidae - minnows

Catostomidae - suckers

Ictaluridae - bullhead catfishes

Salmonidae - trouts

Percopsidae - trout-perches

Aphredoderidae - pirate-perch

Amblyopsidae - cavefishes

Atherinidae - silversides

Fundulidae - killifishes

Poeciliidae - livebearers

Gasterosteidae - sticklebacks

Cottidae - sculpins

Moronidae - striped basses

Centrachidae - sunfishes

Percidae - perches

Sciaenidae - drums

\begin{tabular}{lll}
\hline Totals & $\mathbf{2 1 7}$ & $\mathbf{2 0 0}$ \\
\hline Rio Tiete, Sao Paulo, Brazil & \\
Clupeidae - herrings & & \\
Parodontidae - scrapetooths & 1 & 1 \\
Curimatidae - toothless characins & 2 & 1 \\
Crenuchidae - South American darters & 3 & $1+$ ? \\
Characidae- characids & 18 & $12+2 ?$ \\
Erythrinidae - trahiras & 2 & 2 \\
Trichomycteridae - pencil catfishes & 2 & 2 \\
Callichthyidae - armored catfishes & 4 & 2 \\
Loricariidae - armored catfishes & 6 & $4+?$ \\
Heptapteridae - three-barbeled catfishes & 5 & $3+?$ \\
Gymnotidae - naked-back knifefishes & 2 & 2 \\
Sternopygidae - glassknifefishes & 1 & 1 \\
Poecilidae- livebearers & 2 & 2 \\
Cichlidae - cichlids & 5 & $4+?$ \\
Centrarchidae - sunfishes & 1 & 1 \\
Synbranchidae - swamp eels & 1 & $?$ \\
\hline Totals & 59 & $39+9 ?$ \\
All Fishes & 34,3003 & $20,067^{4}$ \\
\hline
\end{tabular}

Table 2: Availability of DNA barcode reference sequences by vertebrate Class

\begin{tabular}{lll}
\hline Class & $\begin{array}{l}\text { Number } \\
\text { of species }\end{array}$ & $\begin{array}{l}\text { Number with } \\
\text { reference } \\
\text { sequences }\end{array}$ \\
\hline Myxini - hagfishes & 65 & 32 \\
Petromyzontida - lampreys & 44 & 44 \\
Chondrichthyes - sharks & 900 & 987 \\
Sarcopterygii - lobe-finned fishes & 8 & 8 \\
Actinopterygii - bony fishes & 30,000 & 18,996 \\
Amphibia - amphibians & 8,100 & 3,115 \\
Reptilia- reptiles & $9,500+$ & 2,273 \\
Aves - birds & $10,000+$ & 5,234 \\
Mammalia - mammals & $5,700+$ & 3,159 \\
\hline
\end{tabular}

Chlrogastercornutus, which has a regional distribution, surprisingly had no reference sequence. Overall, over $90 \%$ of Virginia freshwater fishes had reference $\mathrm{CO}$ sequences in the BOLD database, making DNA barcoding aviable approach for ready use for many applications in Virginia.

The results for freshwater fishes of Virginia are representative of those for all freshwater fishes of North America. April et al. (2011) generated DNA barcodes derived from expertidentified museum specimens for 752 North American freshwater fish species, representing over $80 \%$ of the named freshwater fishes. Approximately, $90 \%$ of known species could be delineated using barcodes. Interestingly, their results showed numerous instances of independently evolving lineages within described species, suggesting the presence of morphologically cryptic diversity even within the relatively well-investigated North American freshwater fish fauna. Among the 752 species analyzed, April et al. (2011) identified 138 named species that represent as many as 347 candidate species, suggesting a possible $28 \%$ increase in species-level diversity. In contrast, several species of parasitic and nonparasitic lampreys lacked distinct molecular differentiation and, hence, represent alternative life-history strategies within single species. The authors identified 151 fish species for which taxonomic revision is required.

The reference database for freshwater fishes in other regions of the world is less complete. Many of the yetundescribed fish species in the world are in the Neotropical region, and Table 1 shows the results of a case study of fishes of the Rio Tiete in Sao Paulo state of Brazil. Among 59 species of freshwater fishes listed as occurring in the watershed (Marceniuk et al., 2011), 39 clearly had reference sequences in the BOLD database. Among those that that did not, 10 were newly recognized, undescribed species. In four cases, the BOLD database had archived sequences (e.g., Loricariidae Pareiorhina sp.) that seemed to correspond to the new, undescribed species. However, unless that particular lineage had been collected within that watershed, it is problematic to unequivocally associate the species listed by Marceniuk et al. 
(2011) with the archived BOLD sequence.

The reference database for fishes globally is very incomplete. Among fish species, 20,067 have DNA barcode reference sequences in the BOLD (2020) database among 34,300 described fish species globally (Froese and Pauly 2020), for coverage of $58 \%$. This finding shows that much more baseline work is required to make DNA barcoding of fishes useful globally.

While vertebrates are relatively well known and investigated, invertebrate taxa are less so, and hence are less well represented in $\mathrm{CO}$ sequence databases. This issue has considerable practical interest. Biomonitoring of aquatic ecosystems is often approached by identification of benthic invertebrates and assessment of whether they indicate healthy or impacted ecosystem structure and function. For many taxa, however, morphological identification is possible only at limited taxonomic resolution, in some cases restricted to genus or family (Caesar et al., 2006). For example, the midges or chironomids, important macroinvertebrates of freshwater communities, are often treated at family level because of difficulty in identifying specimens at lower taxonomic levels (Beerman et al., 2018). By easing species identification, DNA barcoding may enhance the effectiveness of ecosystem biomonitoring (Sweeney et al., 2011). The effectiveness of DNA barcoding as a tool, however, is highly dependent on the reliability and coverage of DNA sequence reference libraries. For example, Specchia et al. (2020) found that $42 \%$ of the 1,546 examined aquatic macroinvertebrate species of the Apulia region in southeast Italy do not have representative DNAbarcodes in the reference libraries.

This local finding is represents of a larger, regional issue. Weigant et al. (2019) analyzed gaps in the BOLD and GenBank databases, focusing on the full range of taxa most frequently used in European freshwater and marine biomonitoring assessments. Their results showed that coverage varies strongly among taxonomic groups and among geographic regions. In general, groups that were actively targeted in barcode projects (e.g., fishes, true bugs, caddisflies and vascular plants) were well represented in the barcode libraries, while others (e.g., marine mollusks, ascidians, and freshwater diatoms) had relatively few records. Species monitored in several countries are often represented by barcodes in reference libraries, while species monitored in a single country frequently lack DNA sequence records. Up to $50 \%$ of species in several taxonomic groups are represented only by private data in BOLD. These results have implications for strategy to fill the existing gaps in DNA barcode libraries.

Often, high DNA barcoding coverage follows from high interest in a particular regional faunal group. For example, Kerr et al. (2007) performed a comprehensive analysis of DNA barcodes for North American birds, 643 species representing $93 \%$ of the breeding and pelagic avifauna of the United States and Canada.
Most (94\%) species exhibited distinct barcode clusters, with the remaining $6 \%$ corresponding to small sets of closely related species, most of which hybridize. Fifteen $(2 \%)$ currently recognized species comprised of two distinct barcode clusters, which may represent cryptic species. Dinca et al. (2010) barcoded nearly all butterfly species known from Romania and found that $90 \%$ of the species formed distinct barcode clusters supporting reliable identification. The remaining cases involved nine closely related species pairs whose taxonomic status is controversial or that hybridize regularly. DNA barcoding was found to be the most effective identification tool, outperforming external morphology, including male genitalia. Many species of tussock moths of Genus Lymantria are forestry pests, including the gypsy moth Lymantria dispar L. De Waard et al. (2010) assessed the utility of $\mathrm{CO}$ barcoding for identifying species and source populations, concluding that the approach has substantial potential for biosecurity and surveillance.

To provide a global sense of coverage of DNA barcodes, Table 2 compares the number of species in each class of vertebrates with the availability of DNA barcode reference sequences in the BOLD database. While some small classes (Petromyzontida - lampreys, Chondrichthyes - sharks, and Sarcopterygii - lobe-finned fishes) were well represented, the more speciose classes, especially those occurring in developing countries, were much less thoroughly represented. This finding points to the work that must be done to bring DNA barcoding to its full potential utility for these regional faunal groups.

When use of DNA sequences as 'barcodes' and the mitochondrial $\mathrm{COI}$ gene were first proposed as the basis for a system of identification of animals, the response was mixed. While some argued that use of such an approach would compromise hypothesis-driven analysis of evolution and species boundaries, other argued that DNA barcoding is intended as a molecular diagnostic tool in aid of research for many applications, not as a substitute for more intensive phylogenetic studies. The body of material presented in this review supports the view that DNA barcoding advances a variety of practical applications in environmental biology research. DNA barcoding methodology is relatively straightforward and easy to apply, and can bring species identification into reach for a range of applications where identification using morphological characters alone is not straightforward. Research on the development of PCR primers and reference DNA sequence databases are in progress, to which individual laboratories can contribute, and which over time are being more thoroughly addressed.

\section{Acknowledgments}

The participation of E.H. in this work was supported in part by the Virginia Agricultural Experiment Station and the U.S. Department of Agriculture National Institute of Food and Agriculture. Alexandre Hilsdorf suggested useful readings on DNA barcoding of Neotropical fishes. 


\section{Add-on Information}

Author' contribution: Conception, Literature review, $2^{\text {nd }}$ drafting of the manuscript.

Research content: The research contents is original and has notbeen published elsewhere

Ethical approval: NotApplicable

Conflict of interest: The author declares that there is no conflict of interest.

\section{Data from other sources: NotApplicable}

Consent to publish: Author agree to publish the paper in Journal of Environmental Biology.

\section{References}

Akrim, F., T. Mahmood, T. Max, M.S. Nadeem, S. Qasim and S. Andleeb: Assessment of bias in morphological identification of carnivore scats confirmed with molecular scatology in North-eastern Himalayan region of Pakistan. Peer J., 6, e5262 (2018).

Altschul, S.F., W. Gish, W. Miller, E.W. Myers and D.J. Lipman: Basic local alignment search tool. J. Mole. Biol., 215, 403-410 (1990).

April, J., R.L. Mayden, R.H. Hanner and L. Bernatchez: Genetic calibration of species diversity among North America's freshwater fishes. Proc. Natl. Acad. Sci. USA, 108, 10602-10607 (2011).

Arruda, P.S.S., D.C. Ferreira, C. Oliveira and P.C. Venere: DNA barcoding reveals high levels of divergence among mitochondrial lineages of Brycon (Characiformes, Bryconidae). Genes, 10, 639, (2019).

Baker, C.S., F. Cipriano and S.R. Palumbi: Molecular genetic identification of whale and dolphin products from commercial markets in Korea and Japan. Molec. Ecol., 5, 671-685 (1996).

Baker, C.S. and S.R. Palumbi: Which whales are hunted? A molecular genetic approach to monitoring whaling. Science, 265, 1538-1539 (1994).

Barnes, M.A. and C.R. Turner: The ecology of environmental DNA and implications for conservation genetics. Conserv. Genet., 17, 1e17 (2016).

Bass, D., G.D. Stentiford, D.T.J. Littlewood and H. Hartikainen: Diverse applications of environmental DNA methods in parasitology. Tr. Parasitol., 31, 499-513 (2015).

Beermann, A.J., V.M. Zizka, V. Elbrecht, V. Baranov and F. Leese: DNA metabarcoding reveals the complex and hidden responses of chironomids to multiple stressors. Environ. Sci. Eur., 30, 26 (2018).

Begerow, D., R.H. Nilsson, M. Unterseher and W. Maier: Current state and perspectives of fungal DNA barcoding and rapid identification procedures. Appl. Microbiol. Biotechnol., 87, 99-108 (2010).

Benzaquem, D.C. C. Oliveira, J. da Silva Batista, J. Zuanon and J.I.R. Porto: DNA barcoding in pencilfishes (Lebiasinidae: Nannostomus) reveals cryptic diversity across the Brazilian Amazon. PLoS ONE, 10, e0112217 (2015).

Besansky, N.J., D.W. Severson and M.T. Ferdig: DNA barcoding of parasites and invertebrate disease vectors: What you don't know can hurt you. Trends Parasitol., 19, 545-546 (2003).

Bhattacharya, M., A.R. Sharma, B.C. Patra, G. Sharma, E.M. Seo and J.S. Nam: DNA barcoding in fishes: Current status and future directions. Mitochon. DNA PartA, 27, 2744-2752 (2016).

Bohman, K., A. Evans, M.T.P. Gilbert, G.R. Carvalho, S. Greer, M. Knap, D.W. Yu and M. de Bruyn: Environmental DNA for wildlife biology and biodiversity monitoring. Tr. Ecol. Evol., 29, 358-367 (2014).

BOL: Barcode of Life. http://www.boldsystems.org/.Accessed August 11, 2020.

Branicki, W., T. Kupiec and R. Pawlowski: Validation of cytochrome b sequence analysis as a method of species identification. $J$. Forensic Sci., 48, 1-5 (2003).

Brown, V.A., E.V. Willcox, K.E. Fagan and R.F. Bernard: Identification of south-eastern bat species using non-invasive genetic sampling of individual guano pellets. J. Fish Wildl. Manage., 8, 632-639 (2017).

Buckwalter, J., P.L. Angermeier, J. Argentina, S. Wolf, S. Floyd and E.H. Hallerman: Drift of larval darters (Family Percidae) in the upper Roanoke River basin, USA, characterized using phenotypic and DNA barcoding markers. Fishes, 4, 59 (2019).

Bunholi, I.V., B.L.D.S. Ferrette, J.B. De Biasi, C.D.O. Magalhaes, M.M. Rotundo, C. Oliveira, F. Foresti and F.F. Mendonca: The fishing and illegal trade of the angelshark: DNA barcoding against misleading identifications. Fish. Res., 206, 193-197 (2018).

Burghart, S.E., L. Van Woudenberg, C.A. Daniels, S.D. Meyers, E.B. Peebles and M. Breitbart: Disparity between planktonic fish egg and larval communities as indicated by DNA barcoding. Mar. Ecol. Prog. Ser., 503, 195-204 (2014).

Caesar, R.M., M. Sörensson and A.I. Cognato: Integrating DNA data and traditional taxonomy to streamline biodiversity assessment: An example from edaphic beetles in the Klamath ecoregion, California, USA. Divers. Distrib., 12, 483-489 (2006).

Campton, D.E.: Natural hybridization and introgression in fishes: Methods of detection and genetic interpretations. In: Population Genetics and Fishery Management (Eds.: N. Ryman and F. Utter). University of Washington Press, Seattle, pp. 241-263 (1987).

Cashner, M.F. and H.L. Bart: Reproductive ecology of nest associates: Use of RFLPs to identify cyprinid eggs. Copeia, 2010, 554-557 (2010).

Chaves, P.B., V.G. Graeff, M.B. Lion, L.R. Oliveira and E. Eizirik: DNA barcoding meets molecular scatology: Short mtDNA sequences for standardized species assignment of carnivore noninvasive samples. Molec. Ecol. Resour., 12, 18-35 (2012).

Clare, E.L., B.K. Lim, M.D. Engstrom, J.L. Eger and P.D. Hebert: DNA barcoding of Neotropical bats: Species identification and discovery within Guyana. Molec. Ecol. Notes, 7, 184-190 (2007).

Clare, E.L., B.K. Lim, M.B. Fenton and P.D. Hebert: Neotropical bats: Estimating species diversity with DNA barcodes. PLOS ONE, 6, e22648 (2011).

Coissac, E., T. Riaz and N. Puillandre: Bioinformatic challenges for DNA metabarcoding of plants and animals. Molec. Ecol., 21, 1834-1847 (2012).

Coleman, L.S., W.M. Ford, C.A. Dobony and E.R. Britzke: Effect of passive acoustic sampling methodology on detecting bats after declines from white nose syndrome. J. Ecol. Nat. Environ., 6, 5664 (2014).

Cote, I.M., S.J. Green, J. Morris, J.L. Akins and D. Steinke: Diet richness of Indo-Pacific lionfish revealed by DNA barcoding. Mar. Ecol. Progr. Seri., 472, 249-256 (2013).

Creer, S., K. Deiner, S. Frey, D. Porazinska, P. Taberlet, W.K. Thomas, C. Potter and H.M. Bik: The ecologist's field guide to sequence-based identification of biodiversity. Meth. Ecol. Evol., 7, 1008-1018 (2016).

Cywinska, A., F.F. Hunter and P.D. Hebert: Identifying Canadian mosquito species through DNA barcodes. Med. Vet. Entom., 20, 413-424 (2006).

Dawnay, N., R. Ogden, R. McEwing, G.R. Carvalho and R.S. Thorpe: 
Validation of the barcoding gene $\mathrm{CO}$ for use in forensic genetic species identification. Forensic Sci. Intl., 173, 1-6 (2007).

Deagle, B.E., S.N. Jarmin, D. Pemberton and N.J. Gales: Genetic screening in the gut contents from a giant squid, Archituthus sp. J. Hered., 96, 417-423 (2005).

Deiner, K., J. Walser, E. McEachler and F. Altermatt: Choice of capture and extraction methods affect detection of freshwater biodiversity from environmental DNA. Biol. Conserv., 183, 53-63 (2015).

De Waard, J.R., A. Mitchell, M.A. Keena, D. Gopurenko and L.M. Boykin: Towards a global barcode library for Lymantria (Lepidoptera: Lymantriinae). PLOS ONE, 5, e14230 (2010).

Dincă, V., E.V. Zakharov, P.D. Hebert and R. Vila: Complete DNA barcode reference library for a country's butterfly fauna reveals high performance for temperate Europe. Proc. Royal Soc. B: Biol. Sci., 278, 347-355 (2011).

Epp, L.S., S. Boessenkool, E.P. Bellemain, J. Haile, A. Esposito, T. Riaz, C. Erseus, V.I. Gusarov, M.E. Edwards, A. Johnsen, H.K. Stenøien, K. Hassel, H. Kauserud, N.G. Yoccoz, K.A. Bråthen, E. Willerslev, P. Taberlet, E. Coissac and C. Brochmann: New environmental metabarcodes for analysing soil DNA: Potential for studying past and present ecosystems. Molec. Ecol., 21, 18211833 (2012).

Falke, J.A., K.D. Fausch, K.R. Bestgen and L.L. Bailey: Spawning phenology and habitat use in a Great Plains, USA, stream fish assemblage: An occupancy estimation approach. Can. J. Fish. Aquat. Sci., 67, 1942-1956 (2010).

Ferri, E., M. Barbuto, O. Bain, A. Galimberti, S. Uni, R. Guerrero, H. Ferté, C. Bandi, C. Martin and M. Casiraghi: Integrated taxonomy: Traditional approach and DNA barcoding for the identification of filarioid worms and related parasites (Nematoda). Front. Zool., 6 , 1-2(2009).

Ficetola, G.F., C. Miaud, F. Pompanon and P. Taberlet: Species detection using environmental DNA from water samples. Biol. Lett., 4, 423425 (2008).

Froese, R. and D. Pauly. Editors. FishBase. World Wide Web electronic publication. www.fishbase.org. Accessed August 15, 2020.

Fu, Z., M.J. Toda, N.N. Li, Y.P. Zhang and J.J. Gao: A new genus of anthophilous drosophilids, Impatiophila (Diptera, Drosophilidae): morphology, DNA barcoding and molecular phylogeny, with descriptions of thirty-nine new species. Zootaxa, 4120, 1-100 (2016).

Geluso, K., E.C. Keele, N.M. Pauley, I.R. Gomez and S.P. Tye: Nightroosting behaviors for the northern long-eared myotis (Myotis septentrionalis) under a bridge revealed by time-lapse photography. Amer. Midl. Natur., 179, 287-293 (2018).

Gibson, J.F., S. Shokralla, C. Curry, D.J. Baird, W.A.Monk, I. King and M. Hajibabaei: Large-scale biomonitoring of remote and threatened ecosystems via high-throughput sequencing. PLOS ONE, 10, e0138432 (2015)

Goldberg, C.S., D.S. Pilliod, R.S. Arkle and L.P. Waits: Molecular detection of vertebrates in stream water: A demonstration using Rocky Mountain tailed frogs and Idaho giant salamanders. PLOS ONE, 6, e22746 (2011).

Goldberg, C.S., C.R. Turner, K. Deiner, K.E. Klymus, P.F. Thomsen, M.A. Murphy, S.F. Spear, A. McKee, S.J. Oyler-McCance, R.S. Cornman, M.B. Laramie, A.R. Mahon, R.F. Lance, D.S. Pilliod, K.M. Strickler, L.P. Waits, A.K. Fremier, T. Takahara, J.E. Herder and P. Taberlet: Critical considerations for the application of environmental DNA methods to detect aquatic species. Meth. Ecol. Evol., 7, 1299-1307 (2016).

Hallerman, E.: Forensics. In: Population Genetics: Principles and Applications for Fisheries Scientists. (Ed.: E. Hallerman). American Fisheries Society, Bethesda, MD, pp. 395-402 (2003).

Hebert, P.D.N., A. Cywinska and S.L. Ball. Biological identifications through DNA barcodes. Proc. Roy. Soc. London Ser. B: Biol. Sci., 270, 313-321 (2003a).

Hebert, P.D., S. Ratnasingham and J.R. De Waard: Barcoding animal life: Cytochrome $\mathrm{C}$ oxidase subunit 1 divergences among closely related species. Proc. Royal Soc. Lond. Ser. B: Biol. Sci., 270 (Suppl_1), S96-99 (2003b).

Hering, D., A. Borja, J.I. Jones, D. Pont, P. Boets, A. Bouchez, K. Bruce, S. Drakare, B. Hanfling, M. Kahlert, F. Leese, K. Meissner, P. Mergen, Y. Reyjol, P. Segurado, A. Vogler and M. Kelly: Implementation options for DNA-based identification into ecological status assessment under the european water framework directive. Water Res., 138, 192-205 (2018).

Hernández-Dávila, A., J.A. Vargas, N. Martinez-Mendez, B.K. Lim, M.D. Engstrom and J. Ortega: DNA barcoding and genetic diversity of phyllostomid bats from the Yucatan Peninsula with comparisons to Central America. Molec. Ecol. Resour., 12, 590-597 (2012).

Hilling, C.D., S.L. Wolf, J.R. Copeland, D.J. Orth and E.M. Hallerman: Occurrence of two non-indigenous catostomid fishes in the New River, Virginia. Northeast. Nat., 25, 215-221 (2018).

Hollingsworth, P.M., S.W. Graham and D.P. Little: Choosing and using a plant DNA barcode. PLoS ONE, 6, e19254 (2011).

Hopkins, R.M., B.P. Meloni, D.M. Groth, J.D. Wetherall, J.A. Reynoldson and R.A. Thompson: Ribosomal RNA sequencing reveals differences between the genotypes of Giardia isolates recovered from humans and dogs living in the same locality. J. Parasitol., 83, 44-51 (1997)

Huang, Z., C. Yang and D. Ke: DNA barcoding and molecular phylogeny in Ranidae. Mitochon. DNAPartA, 27, 4003-4007 (2016).

Huffman, J.E. and J.R. Wallace: Wildlife Forensics: Methods and Implications. Wiley-Blackwell, Oxford, UK (2012). doi: 10.1002/9781119953142

Hulley, E.N., N.D.J. Taylor, A.M. Zarnke, C.M. Somers, R.G. Manzon, J.Y. Wilson and D.R. Boreham: DNA barcoding vs morphological identification of larval fish and embryos in Lake Huron: Advantages to a molecular approach. J. Great Lakes Res., 44, 1110-1116 (2018).

Hyde, K.D., D. Udayanga, D.S. Manamgoda, L. Tedersoo, E. Larsson, K. Abarenkov, B. Yann, B. Oxelman, M. Hartmann, H. Kauserud, M. Ryberg, E. Kristiansson and R.H. Nilsson: Incorporating molecular data in fungal systematics: A guide for aspiring researchers. Curr. Res. Environ. Appl. Mycol., 3, 1-32 (2013).

Ivanova, N.V., T.S. Zemlak, R.H. Hanner and P.D.N. Herbert: Universal primer cocktails for fish DNA barcoding. Molec. Ecol. Notes, 7, 544-548 (2007).

Janosik, A. and C. Johnston: Environmental DNA as an effective tool for detection of imperiled fishes. Environ. Biol. Fishes, 98, 1889-1893 (2015).

Jedlicka, J.A., A.T. Vo and R.P. Almeida: Molecular scatology and highthroughput sequencing reveal predominately herbivorous insects in the diets of adult and nestling western bluebirds (Sialia mexicana) in California vineyards. Auk, 134, 116-127 (2017).

Jenkins, R.E. and N.M. Burkhead: Freshwater Fishes of Virginia. American Fisheries Society, Bethesda, MD, p. 1080 (1994).

Jerde, C.L., A.R. Mahon, W.L. Chadderton and D.M. Lodge: "Sightunseen" detection of rare species using environmental DNA. Conserv. Lett., 4, 150-157 (2011).

Jiang, K.W., R. Zhang, Z.F. Zhang, B. Pan and B. Tian: DNA barcoding and molecular phylogeny of Dumasia (Fabaceae: Phaseoleae) reveals a cryptic lineage. Plant Divers, https:// doi.org/ 10.1016/j. pld. 2020.07.007 (2020).

Jo, H., J.A. Gim, K.S. Jeong, H.S. Kim and G.J. Joo: Application of DNA barcoding for identification of freshwater carnivorous fish diets: Is 
number of prey items dependent on size class for Micropterus salmoides? Ecol. Evol., 4, 219-229 (2013).

Johnson, J.B., M.A. Menzel, J.W. Edwards and W.M. Ford: Gray bat night-roosting under bridges. J. Tennessee Acad. Sci., 77, 91-93 (2002).

Johnston, T.A., M.N. Gaboury, R.A. Janusz and L.R. Janusz: Larval fish drift in the Valley River, Manitoba: Influence of abiotic and biotic factors, and relationships with future year-class strengths. Can. J. Fish. Aquat. Sci., 52, 2423-2431 (1995).

Kelso, W.E., M.D. Kaller and D.A. Rutherford: Collecting, processing, and identification of fish eggs and larvae and zooplankton. In: Fisheries Techniques (Eds.: B.R. Murphy and D.W. Willis). $3^{\text {rd }}$ Edn., American Fisheries Society: Bethesda, MD, USA, pp. 363-452 (2012).

Kerr, K.C., M.Y. Stoeckle, C.J. Dove, L.A. Weigt, C.M. Francis and P.D. Hebert: Comprehensive DNA barcode coverage of North American birds. Molec. Ecol. Notes, 7, 535-543 (2007).

Kiser, J.D., J.R. MacGregor, H.D. Bryan and A. Howard: The use of concrete bridges as night roosts by Indiana bats (Myotis sodalis) in South central Indiana. Abstracts of the $29^{\text {th }}$ Annual North American Symposium on Bat Research, Madison WI (1999).

Korstian, J.M., A.M. Hale, V.J. Bennett and D.A. Williams: Using DNA barcoding to improve bat carcass identification at wind farms in the United States. Conserv. Genet. Resour., 8, 27-34 (2016).

Kress, W.J. and D.L. Erickson: DNA barcodes: Methods and protocols. Meth. Molec. Biol., 858, 3-8 (2012).

Kress, W.J., K.J. Wurdack, E.A. Zimmer, L.A. Weigt and D.H. Janzen: Use of DNA barcodes to identify flowering plants. Proc. Natl. Acad. Sci., 102, 8369-8374 (2005).

Kumar, N.P., A.R. Rajavel, R. Natarajan and P. Jambulingam: DNA barcodes can distinguish species of Indian mosquitoes (Diptera: Culicidae). J. Med. Entomol., 44, 1-7 (2007).

Marceniuk, A.P., A.W. Hilsdorf and F.Langeani: The ichthyofauna from the headwaters of the Rio Tietê, São Paulo, Brazil. Biota Neotrop., 11, 217-236 (2011).

Martinez, L., T.B. Johnson, S.A. Ludsin and D.D. Heath: Utilization of stomach content DNA to determine diet diversity in piscivorous fishes. J. Fish Biol., 78, 1170-1182 (2011).

Moran, Z., D.J. Orth, J.D. Schmitt, E.M. Hallerman and R. Aguilar: Effectiveness of DNA barcoding for identifying piscine prey items in stomach contents of piscivorous catfishes. Environ. Biol. Fishes, 99, 161-167 (2016).

Munoz-Colmenero, M., O. Blanco, V. Arias, J.L. Martinez and F. GarciaVazquez: DNA authentication of fish products reveals mislabeling associated with seafood processing. Fisheries, 41, 129-138 (2016).

Nagle, B.C. and A.M. Simons: Rapid diversification in the North American minnow genus Nocomis. Molec. Phylogenet. Evol., 63, 639-649 (2012).

Naus, C.J. and S.R. Adams: Fish nursery habitat function of the main channel, floodplain tributaries and oxbow lakes of a medium-sized river. Ecol. Freshw. Fish, 27, 4-18 (2018).

Near, T.J., C.M. Bossu, G.S. Bradburd, R.L. Carlson, R.C. Harrington, P.R. Hollingsworth, Jr., B.P. Keck and D.A.Etnier: Phylogeny and temporal diversification of darters (Percidae: Etheostomatinae). Syst. Biol., 60, 565-595 (2011).

Niles, J.M. and K.J. Hartman: Larval fish use of dike structures on a navigable river. N. Am. J. Fish. Manag., 29, 1035-1045 (2009).

Nobile, A.B., D. Freitas-Souza, F.J. Ruiz-Ruano, M.L.M.O. Nobile, G.O. Costa, F.P. De Lima, J.P.M. Camacho, F. Foresti and C. Oliveira: DNAmetabarcoding of Neotropical ichthyoplankton: Enabling high accuracy with lower cost. Metabarc. Metagenom., 3, 1-8 (2019).
Ogden, R.: Fisheries forensics: The use of DNA tools for improving compliance, traceability and enforcement in the fishing industry. Fish Fisher., 9, 462-472 (2008).

Ogden, R.: Forensic science, genetics and wildlife biology: Getting the right mix for a wildlife DNA forensics lab. Foren. Sci., Med. Pathol., 6, 172-179 (2010).

Ogedengbe, J.D., R.H. Hanner and J.R. Barta: DNA barcoding identifies Eimeria species and contributes to the phylogenetics of coccidian parasites (Eimeriorina, Apicomplexa, Alveolata). Int. J. Parasitol., 41, 843-850 (2011).

Oliveira, C., G.S. Avelino, K.T. Abe, T.C. Mariguela, R.C. Benine, G. Ortí, R.P. Vari and R.M. Corrêa e Castro: Phylogenetic relationships within the speciose family Characidae (Teleostei: Ostariophysi: Characiformes) based on multilocus analysis and extensive ingroup sampling. BMC Evol. Biol., 11, 275 (2011).

Olson, P.D. and V.V. Tkach: Advances and trends in the molecular systematics of the parasitic Platyhelminthes. Adv. Parasitol., 60, 165-243 (2005).

Pegg, G.G., B. Sinclair, L. Briskey and W.J. Aspden: MtDNA barcode identification of fish larvae in the southern Great Barrier Reef Australia. Sci. Mar., 70, 7-12 (2006).

Peoples, B.K., P. Cooper, E. Hallerman and E.A. Frimpong: DNA barcoding elucidates cyprinid reproductive interactions in a southwest Virginia stream. Trans. Amer. Fish. Soc., 146, 84-91 (2017).

Pereira, L.H.G., R. Hanner, F. Foresti and C. Oliveira: Can DNA barcoding accurately discriminate megadiverse Neotropical freshwater fish fauna? BMC Genet., 14, 20 (2013).

Pereira, L.H.G., M.F. Pazian, R. Hanner, F. Foresti and C. Oliveira: DNA barcoding reveals hidden diversity in the Neotropical freshwater fish (Characiformes: Characidae) from the Upper Paraná Basin of Brazil. Mitochond. DNA, 22, 87-96 (2011).

Ratnasingham, S. and P.D. Hebert: BOLD: The barcode of life data system (http://www.barcodinglife.org). Molec. Ecol. Notes, 7, 355364 (2007).

Rodgers, T.W. and J.E. Janečka: Applications and techniques for noninvasive faecal genetics research in felid conservation. Eur. $J$. Wildl. Res., 59, 1-6 (2013).

Rodríguez-Castro, K.G., B.H. Saranholi, L. Bataglia, D.V. Blanck and P.M. Galetti: Molecular species identification of scat samples of South American felids and canids. Cons. Genet. Resour., 12, 6166 (2020).

Roman, J. and B. Bowen: The mock turtle syndrome: Genetic identification of turtle meat purchased in the south-eastern U.S.A. Anim. Conserv., 3, 61-65 (2000).

Rossini, B.C., C.A.M. Oliveira, F.A.D. de Melo, V.A. Bertaco, J.M. Diaz de Astarloa, J.J. Rosso, F. Foresti and C. Oliveira: Highlighting Astyanax species diversity through DNA barcoding. PLOS ONE, 11, e0167203, (2016).

Ruppert, K.M., R.J. Kline and M.S. Rahman: Past, present, and future perspectives of environmental DNA (eDNA) metabarcoding: A systematic review in methods, monitoring, and applications of global eDNA. Glob. Ecol. Conserv., 17, e00547 (2019).

Schoch, C.L., K.A. Seifer, S, Huhndorf, V. Robert, J.L. Spouge, C.A. Levesque and $W$. Chen: Nuclear ribosomal internal transcribed spacer (ITS) region as a universal DNA barcode marker for fungi. Proc. Natl. Acad. Sci. USA, 109, 6241-6246 (2012).

Scribner, K.T., K.S. Page and M.L. Bartron: Hybridization in freshwater fishes: A review of case studies and cytonuclear methods of biological inference. Rev. Fish Biol. Fisheries, 10, 293-323 (2000).

Seah, A., M.C. Lim, D. McAloose, S. Prost and T.A. Seimon: MinIONbased DNA barcoding of preserved and non-invasively collected 
wildlife samples. Genes, 11, 445 (2020).

Seifert, K.A.: Progress towards DNA barcoding of fungi. Molec. Ecol. Resour., 9, 83-89 (2009).

Silknetter, S.,Y. Kanno, K.L. Kanapeckas-Métris, E. Cushman, T.L. Darden and B.K. Peoples: Mutualism or parasitism: Partner abundance affects host fitness in a fish reproductive interaction. Freshw. Biol., 64, 175-182 (2019).

Smith, P.J., S.M. McVeagh, V. Allain and C. Sanchez: DNA identification of gut contents of large pelagic fish. J. Fish Biol., 67, 1178-1183 (2005).

Specchia, V., E. Tzafesta, G. Marini, S. Scarcella, S. D'Attis and M. Pinna: Gap analysis for DNA barcode reference libraries for aquatic macroinvertebrate species in the Apulia region (Southeast Italy). J. Mar. Sci. Eng., 8, 538 (2020).

Sterud, E., C.M. Collins and C.O. Cunningham: The use of host specificity, pathogenicity, and molecular markers to differentiate between Gyrodactylus salaris Malmberg, 1957 and G. thymalli Zitnan, 1960 (Monogenea: Gyrodactylidae). Parasitology, 124, 203-213 (2002).

Sweeney, B.W., J.M. Battle, J.K. Jackson and T. Dapkey: Can DNA barcodes of stream macroinvertebrates improve descriptions of community structure and water quality? J. North. Am. Benthol. Soc., 30,195-216 (2011).

Taberlet, P., S.M. Prudhomme, E. Campione, J. Roy, C. Miquel, W. Shehzad, L. Gielly, D. Rioux, P. Choler, J. Clement, C. Melodelima, F. Pompanon and E. Coissac: Soil sampling and isolation of extracellular DNA from large amount of starting material suitable for metabarcoding studies. Molec. Ecol., 21, 1816-1820 (2012).

Tavares, E.S. and A.J. Baker: Single mitochondrial gene barcodes reliably identify sister-species in diverse clades of birds. BMC Evol. Biol., 8, 81 (2008).

Thomsen, P.F., J. Kielgast, L.L. Iversen, C. Wiuf, M. Rasmussen, M.T.P. Gilbert, L. Orlando and E. Willerslev: Monitoring endangered freshwater biodiversity using environmental DNA. Molec. Ecol., 21, 2565-2573 (2012).

U.S. Fish and Wildlife Service: Bats Affected by WNS. https://www.whitenosesyndrome.org/static-page/bats-affectedby-wns(2020). Accessed August 20, 2020.
Valdez-Moreno, M., L. Vásquez-Yeomans, M. Elías-Gutiérrez, N.V. Ivanova and P.D. Hebert: Using DNA barcodes to connect adults and early life stages of marine fishes from the Yucatan Peninsula, Mexico: Potential in fisheries management. Mar. Freshw. Res., 61, 655-671 (2010).

Walker, F.M., C.H. Williamson, D.E. Sanchez, C.J. Sobek and C.L. Chambers: Species from feces: Order-wide identification of Chiroptera from guano and other non-invasive genetic samples. PLOSONE, 11, e0162342 (2016).

Wang, J.F. and G.X. Qiao: DNA barcoding of genus Toxoptera Koch (Hemiptera: Aphididae): identification and molecular phylogeny inferred from mitochondrial $\mathrm{CO}$ sequences. Insect Sci., 16, 475484 (2009).

Ward, R.D., T.S. Zemlack, B.H. Innes, P.R. Last and P.D.N. Herbert: DNA barcoding Australia's fish species. Philos. Trans. Roy. Soc. London B: Biol. Sci., 360, 1847-1857 (2005).

Weigand, H., A.J. Beermann, F. Ciampor, F.O. Costa, Z. Csabai, S. Duarte, M.F. Geigerg, M. Grabowski, F. Rimet, B. Rulik, N. Szucsich, A.M. Weigand, E. Willassen, S.A. Wyler, A. Bouchez, A. Borja, Z.Č. Zat'ovičová, S. Ferreira, K. Dijkstra, U.E. Flöckner, J. Freyhof, P. Gadawski, G. Wolfram, A. Hägerbäumer, B. van der hoorn, B. Japoshvili, L. Keresztes, E. Keskin, F. Leese, J.N. Macher, T. Mamos, G. Paz, V. Pešić, D.M. Pfannkuchen, M. Pfannkuchen, B.W. Price, Buki, Rinkevich, M. A L Teixeira, G. Varbiro and T. Ekrem : DNA barcode reference libraries for the monitoring of aquatic biota in Europe: Gap-analysis and recommendations for future work. Sci. Total Environ., 678, 499-524 (2019).

Weigt, L.A., A.C. Driskell, C.C. Baldwin and A. Ormos: DNA barcoding fishes. In: Methods in Molecular Biology. (Eds.: L.D.A. Lopez and D.J. Erickson). Springer, New York, pp.109-126 (2012).

Woese, C.R. and G.E. Fox: Phylogenetic structure of the prokaryotic domain: The primary kingdoms. Proc. Natl. Acad. Sci. USA, 74, 5088-5090 (1977).

Ye, J.,G. Coulouris, I. Zaretskaya, I. Cutcutache, S. Rozen and T. Madden: Primer-BLAST:A tool to design target-specific primers for polymerase chain reaction. BMC Bioinform., 13, 134 (2012). 